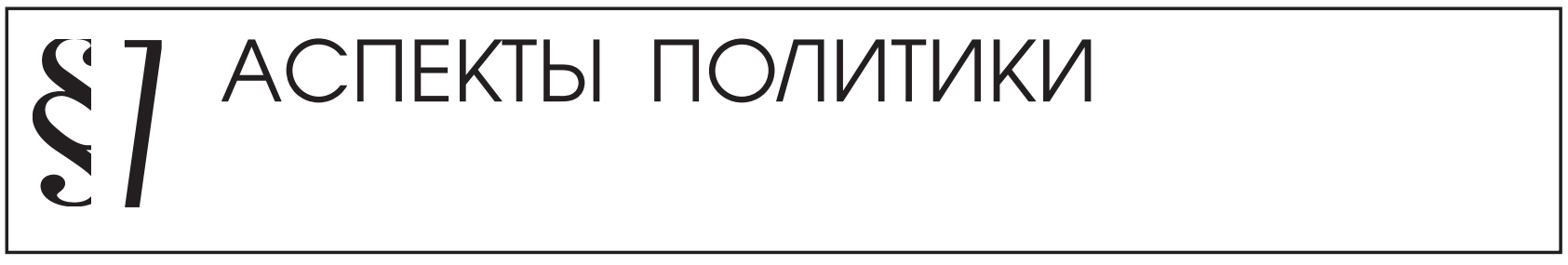

Репинская O.B.

\title{
АНТИТЕРРОРИСТИЧЕСКАЯ СТРАТЕГИЯ КАК СПОСОБ ОБЕСПЕЧЕНИЯ ПОЛИТИЧЕСКОГО ДОМИНИРОВАНИЯ США
}

Аннотация: B статье проводиться анализ антитеррористической стратегии как способа обеспечения политического доминирования США, в контексте обеспечения безопасности России и на Евразийском пространстве. Обосновывается зависимость внешнеполитических прочессов в рамках антитеррористического противодействия в различных регионах мира от обеспечения геостратегических интересов Америки. Рассматриваются тенденции развертывания демократических преобразований и усиления террористической активности на постсоветском пространстве в формате укрепления политики России. Проводиться анализ возможных перспектив развития политического процесса в свете реализации положений Закона США № 2277 «Акт о предотвращении агрессии со стороны России 2014» В основу методологии исследования положены общенаучные методы познания и специальные методы: сочиологический, бихевиористский, сравнительно-правового анализа, статистический, исторический и т.д. Научная новизна исследования, в частности выражается: - в обосновании зависимости направлений антитеррористической политики США от задач обеспечения политического доминирования США;- в установлении связи, существующей между усилением позиции России и всплеском террористической активности в зоне соприкосновения с геостратегическими интересами США;- в обосновании укрепления сотрудничества на Евразийском пространстве в контексте обеспечения антитерроористической безопасности.

Review: The article is devoted to the analysis of the antiterrorist strategy as a mean of enforcing the USA political domination in terms of security enforcement in Russia and Eurasian Zone. The researcher substantiates the dependence of external political processes aimed at antiterrorist measures in different regions of the world on achieving geostrategic interests of America. O. Repinskaya also views the tendencies towards development of democratic transformations and growth of terrorist activity in the post-Soviet territory in terms of strengthening the policy of Russia. The author analyzes possible prospects for the development of the political process in the light of the implementation of provisions of US Law No. 22777 'Russian Aggression Prevention Act of 2014'. The research methodology includes general scientific methods of research as well as special methods such as sociological, behavioral, comparative law, statistical and historical analysis and etc. The scientific novelty of the research is proved by: - the substantiation $f$ the dependence of the US antiterrorist policy directions on the tasks of enforcing the political domination of the USA; - the discovery of the relation between the strengthening Russia's position and the rise of terrorist activity in the territory near the areas of geostrategic interests of the USA; - the conclusion that it is necessary to improve the cooperation in the Eurasian territory for the purpose of anti-terrorist security.

Ключевые слова: Терроризм, безопасность, антитеррористическая стратегия, политическое доминирование, антитеррористическое сотрудничество, США, Россия, Евразийский союз, Европейский союз, Украина. Keywords: Terrorism, security, anti-terrorist strategy, political domination, anti-terrorist cooperation, USA, Russia, Eurasian Union, European Union, Ukraine.

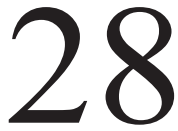
мая 2014 г. (в России День пограничника) президента Америки Барак Хусейн Обама на выпускной церемонии в Военной академии США Уэст-Пойнт (Нью Йорк) вы- ступил с напутственной речью, в которой не только подчеркнул исключительность американской нации «Соединенные Штаты были и остаются единственной незаменимой страной... Я всей душой 
верю в исключительность Америки», ${ }^{1}$ но и открыто заявил о политике устранения конкурентов любым путем, силовым, экономическим и т.д. «от хаоса нас может спасти только готовность Америки применять силу по всему миру... хотя мнение международной общественности очень важно, но Америка ни у кого не будет спрашивать позволения на защиту своего народа, своей земли и своего образа жизни». ${ }^{2}$ Показательно, что все действия по устранению препятствий к лидерству США корелируют в речи Б.Х. Обамы с борьбой с терроризмом. При этом, президент США не скрывает, ни фактов влияния на протестные события в отдельных странах «выработанные нами ценности вдохновляют лидеров в парламентах и новые движения на площадях по всему миру», ${ }^{3}$ ни дальнейших аналоговых действий в данном направлении «мы должны сдвинуть нашу стратегию борьбы с терроризмом в сторону более эффективного партнерства со странами, в которых пытаются окопаться террористы... я призываю Конгресс одобрить создание нового Фонда контртеррористического партнерства в объеме до 5 миллиардов долларов, который даст нам возможность помогать находящимся на передовой борьбы с терроризмом странам-партнерам». ${ }^{4}$

В своей речи, президент США, также заявил о том, что ни одна страна в мире даже в принципе не может противостоять военному могуществу Америки, вспоминая при этом период холодной войны, соответственно имея ввиду современную Россию. Однако, реалии таковы, что США все же приходиться уже не только учитывать усиление России и возможности растущей экономики Китая, но и противостоять им. Вследствие чего в Америке был экстренно подготовлен корректирующий законопроект по устранению усиливающегося влияния России препятствующего гегемонии США (Закон США (BILL) № 2277 «Акт о предотвращении агрессии со стороны России 2014»). Террористическая направленность действий украинских властей в данном акте тушуется под демократические преобразования, которые предусматриваются и для России.

\footnotetext{
${ }^{1}$ Речь Обамы в Военной академии URL: http://www.agregator. pro/rech_obamyi_v_voennoy_akademii.2513024.html Дата обращения 03.07.2014 г.

2 Там же.

${ }^{3}$ Там же.

${ }^{4}$ Там же.
}

Целый «Раздел III. Укрепление Украины и других Европейских и Евразийских государств против Российской агрессии», посвящен вопросам, основная идея которых не допустить экономического укрепления Евразийского региона во главе с Россией. При этом для реализации «Пункта. 206. Поддержка Российской демократии и гражданского общества» разрешается выделить 10,000,000\$ для каждого финансового года (с 2015 до 2017) для целей осуществления плана Президента. В «Разделе III. Укрепление Украины и других Европейских и Евразийских государств против Российской агрессии», первым пунктом указано «Пункт. 301. Военная помощь Украине» (соответственно против России?) разрешается выделить госсекретарю 100,000,000\$ только на 2014 бюджетный год, при этом подробно перечисляются виды поставок вооружений (противотанковое оружие и боеприпасы; зенитное оружие и боеприпасы и др.; ...и другими статьями защиты, услугами и обучением, которое требует правительство Украины). Президент Б. Обама последователен в реализации американской политики: сначала в Уэст-Пойнте он заявил о «готовности Америки применять силу по всему миру», о необходимости выделения расходов под борьбу с терроризмом, а затем, в США принимается «Акт о предотвращении агрессии со стороны России 2014». Исходя из логики президента США, Россия и есть главный координатор мировых террористических сил? Безусловно, для Америки, борьба с терроризмом, всего лишь удобное прикрытие для устранения конкурентов, препятствующих доминированию США в военном, экономическом и политическом смысле. И главным препятствием реализации собственных имперских интересов, исходя из смысла сказанного, Америка видит в укреплении сотрудничества России на Евразийском пространстве.

«Каждое государство обязано уважать суверенитет других участников системы, то есть их право без какого-либо вмешательства со стороны других государств, самостоятельно проводить свою внешнюю политику. Гуманитарная интервенция неизбежно оказывает влияние на жизнь многих народов, зачастую ведет к изменению баланса сил не только в отдельном регионе, но и в глобальном масштабе». ${ }^{5}$ «Как антиколониальное движение, так

\footnotetext{
${ }^{5}$ Карташкин В.А. Гуманитарная интервенция в глобализирующемся мире. Юрист-международник. № 3. 2003. С. 2.
} 


\section{Политика и общество 8 (116) • 2014}

и сегодняшняя волна терроризма суть реакции неразвивающихся сообществ на прогресс западного мира...Запад не может «цивилизовать» мир ислама желательным для себя образом, ему остается только не вставать на пути его децивилизации и минимизировать ее отрицательные последствия. И главной задачей является поиск путей этой минимизации». ${ }^{6}$

Орджоникидзе С.А. отмечает, что «все больше и больше традиционных государственных вопросов передается, условно говоря, в «международную компетенцию». Этот процесс - не отрицание, а проявление принципа суверенитета. Принцип суверенного равенства дает государствам возможность договариваться, ибо делать это можно только на равных. Ставить под вопрос этот принцип, значит ставить под вопрос и само международное право». ${ }^{7}$ Тем более, если речь идет о неодобрении методов ведения антитеррористической борьбы США.

В.В. Путин справедливо отмечал: «если мы допустим, чтобы на смену международному праву пришло кулачное право, согласно которому сильный всегда прав, имеет право на все, а при выборе средств для достижения своих целей ничем не ограничен, тогда под вопрос будет поставлен один из базовых принципов международного права, принцип незыблемости суверенитета государства. И тогда никто, ни одна страна мира не будет чувствовать себя в безопасности». ${ }^{8}$

«Такая политика, якобы направленная против международного и национального терроризма, по существу сама может быть квалифицирована как международный терроризм». ${ }^{9}$ Примером являются действия США на Балканах, в Ираке, Афганистане, в Украине, контртерористическая операция Израиля в секторе ГАЗА, и другие акции, в ходе которых погибли сотни мирных людей, В том числе дети.

Глобализация ведет к росту зависимости процесса реализации национальных интересов тех или иных стран от действий и решений, принимаемых далеко за пределами их территории другими субъектами меж-

\footnotetext{
${ }^{6}$ Иноземцев В.А. Терроризм как антипод глобализации// Независимая газета, 26.09.2005. №206(3602), С.14.

7 Дипломатический вестник. 1999. № 7. С. 81

${ }^{8}$ Цит. по: Право и безопасность. № 3-4 (8-9). 2003. С.31.

${ }^{9}$ Бруснииын Ю.А. Актуальные проблемы борьбы с терроризмом// Борьба с терроризмом: актуальные проблемы законодательного обеспечения: Сборник научных статей//Ростовна-Дону, РЮИ МВД России, 2003. С..57.
}

дународных отношений, а также к обострению противоречий между основной функцией государства по обеспечению собственного суверенитета и вышеуказанной зависимостью при принятии политических решений от ситуации в мировом сообществе в целом. Вместо того чтобы направлять усилия и деньги на финансирование терроризма для совершения очередных революций для создания в этих странах режима максимального благоприятствования колониантам, вместо того, чтобы тратить деньги на разрушение чужих экономик, возможно целесообразнее направить средства на погашение американского государственного долга, который в 2014 году по прогнозам составит порядка 18532 млрд. \$ США, ${ }^{10}$ что составит около 109,9\% от ВВП страны. Для сравнения «после распада СССР внешний долг России неуклонно возрастал и достиг своего максимума сразу после кризиса 1998 года, когда он достиг 146,4 \% от ВВП страны». ${ }^{11}$

Таким образом, антитеррористическая стратегия США направлена ни сколько на противодействие (а иногда даже помощь террористам), сколько на обеспечение доминирования США в военном, экономическом и политическом смысле. Соответственно, исполнение международных договоренностей в рамках противодействия терроризму будут носить либо формальный характер, либо не будут исполняться вообще, а в случае расхождения с интересами США, скорее даже нарушаться.

Предложения пересмотреть ранее заключенные и ратифицированные международные договора, соглашения, конвенции, на предмет соответствия интересам национальной безопасности России были озвучены заместителем председателя комитета Совета Федерации по конституционному законодательству и государственному строительству К. Добрыниным в июле 2014 года. ${ }^{12}$ В условиях действия «обнажен-

${ }^{10}$ Государственный долг CША URL:http://ru.wikipedia.org/ wiki/\%C3\%EE $\%$ F1\%F3\%E4\%E0\%F0\%F1\%F2\%E2\%E5\%ED $\% \mathrm{ED} \% \mathrm{FB} \% \mathrm{E} 9 \_\% \mathrm{E} \% \mathrm{EE} \% \mathrm{~EB} \% \mathrm{E} 3$ _\%D1\%D8\%C0 Дата обращения 03.07.2014 г.

${ }^{11}$ Внешний долг России URL: http://ru.wikipedia.org/wiki/\%C $2 \%$ ED $\%$ E5\%F8\%ED\%E8\%E9 \%E4\%EE\%EB\%E3 \%D0\%EE $\% \mathrm{~F} 1 \% \mathrm{~F} 1 \% \mathrm{E} 8 \% \mathrm{E} 8$ Дата обращения 03.07.2014 г.

12 Россия собирается пересмотреть и разорвать некоторые международные договоры / Новости Украины 30.07.2014 URL: http://www.from-ua.com/news/316888-rossiya-hochetperesmotret-mezhdunarodnie-dogovori-na-predmet-denonsacii. $\mathrm{html}$ Дата обращения 31.07.2014 г. 
ной» политики, когда перестает скрываться заинтересованность в определенных политических процесcax (например, США в Украине не скрывают своих претизаний, факта спонсирования, военного и раз- ведывательного обеспечения), пересмотр политикоправовых документов, не отвечающих требованиям национальной безопасности, самый малый шаг на пути к обеспечению биполярного мира.

\section{Библиография:}

1. Речь Обамы в Военной академии URL: http://www.agregator.pro/rech_obamyi_v_voennoy_akademii.2513024.html Дата обращения 03.07.2014 г.

2. Карташкин В.А. Гуманитарная интервенция в глобализирующемся мире. Юрист-международник. № 3. С. 2.

3. Иноземцев В.А.Терроризм как антипод глобализации// Независимая газета, 26.09.2005. №206(3602), С.14.

4. Дипломатический вестник. 1999. № 7. С.81.

5. Право и безопасность. № 3-4 (8-9). 2003. С.31.

6. Брусницын Ю.А. Актуальные проблемы борьбы с терроризмом// Борьба с терроризмом: актуальные проблемы законодательного обеспечения: Сборник научных статей//Ростов-на-Дону, РЮИ МВД России, 2003. С..57.

7. Государственный долг США URL:http://ru.wikipedia.org/wiki/\%C3\%EE\%F1\%F3\%E4\%E0\%F0\%F $\%$ FF2\%E2\%E5\%E D\%ED\%FB\%E9_\%E4\%EE\%EB\%E3_\%D1\%D8\%C0 Дата обращения 03.07.2014 г.

8. Внешний долг России URL: http://ru.wikipedia.org/wiki/\%C2\%ED\%E5\%F8\%ED\%E8\%E9_\%E4\%EE\%EB\%E3_\%D0 $\% \mathrm{EE} \% \mathrm{~F} 1 \% \mathrm{~F} 1 \% \mathrm{E} 8 \% \mathrm{E} 8$ Дата обращения 03.07.2014 г.

9. Россия собирается пересмотреть и разорвать некоторые международные договоры / Новости Украины 30.07 .2014 URL: http:/www.from-ua.com/news/316888-rossiya-hochet-peresmotret-mezhdunarodnie-dogovori-na-predmet-denonsacii. html Дата обращения 31.07.2014 г.

10. Бочарников И.В. Украинский кризис как элемент пояса стратегического окружения России // NB: Международные отношения. - 2014. - 4. - C. 7-32. DOI: 10.7256/2306-4226.2014.4.11617. URL: http://www.e-notabene.ru/wi/ article_11617.html

11. О. Г. Карпович. Миротворческая деятельность США и англосаксонские технологии управления международными конфликтами. // Национальная безопасность / nota bene. - 2012. - № 1. - С. 64-74.

12. Д.И. Иванова. Антитеррористическая политика ООН и стратегия контроля над международным терроризмом. // Национальная безопасность / nota bene. - 2009. - № 1

\section{References (transliteration):}

1. Kartashkin V.A. Gumanitarnaya interventsiya v globaliziruyushchemsya mire. Yurist-mezhdunarodnik. № 3. S. 2.

2. Inozemtsev V.A.Terrorizm kak antipod globalizatsii// Nezavisimaya gazeta, 26.09.2005. №206(3602), S.14.

3. Brusnitsyn Yu.A. Aktual'nye problemy bor'by s terrorizmom// Bor'ba s terrorizmom: aktual'nye problemy zakonodatel'nogo obespecheniya: Sbornik nauchnykh statei//Rostov-na-Donu, RYuI MVD Rossii, 2003. S..57.

4. Bocharnikov I.V. Ukrainskii krizis kak element poyasa strategicheskogo okruzheniya Rossii // NB: Mezhdunarodnye otnosheniya. - 2014. - 4. - C. 7-32. DOI: 10.7256/2306-4226.2014.4.11617. URL: http://www.e-notabene.ru/wi/article 11617.html

5. O. G. Karpovich. Mirotvorcheskaya deyatel'nost' SShA i anglosaksonskie tekhnologii upravleniya mezhdunarodnymi konfliktami. // Natsional'naya bezopasnost' / nota bene. - 2012. - № 1. - C. 64-74.

6. D.I. Ivanova. Antiterroristicheskaya politika OON i strategiya kontrolya nad mezhdunarodnym terrorizmom.. // Natsional'naya bezopasnost' / nota bene. - 2009. - № 1 